\title{
Economic Valuation of Mountain Landscapes and Ecosystems: A Meta-Analysis of Case Studies
}

\author{
Z. Žáková Kroupová, M. Havlíková, P. Hálová, M. Malý
}

Faculty of Economics and Management, Czech University of Life Sciences Prague, Czech Republic

\begin{abstract}
The paper is focused on the value of the European mountain landscape/ecosystem and evaluates the impact of agriculture and agricultural policy on the value of this public good. Based on the meta-analysis of 22 landscape/ecosystem valuation studies, it was found that the average value of the European mountain landscape/ecosystem is 3,068 EUR per hectare per year, and 3.91 EUR per person per day. However, there are regions with a significantly higher value - Tatra in Poland and Alpujarran in Spain. The value is influenced by the position of agriculture in the national economy. Higher values of the mountain landscape/ ecosystem were achieved in countries where the contribution of agriculture to the gross value added is above average. On the other hand, there is no significant relationship between the proportion of farming in the LFA and the value of the mountain landscape/ecosystem. Public support was found to be insufficient to cover the cost of landscape services performed by farmers.
\end{abstract}

\section{Keywords}

Mountain, landscape, ecosystem, value, agriculture, LFA, Europe, meta-analysis.

Žáková Kroupová, Z., Havlíková, M., Hálová, P., M. Malý (2016) “Economic Valuation of Mountain Landscapes and Ecosystems: A Meta-Analysis of Case Studies", AGRIS on-line Papers in Economics and Informatics, Vol. 8, No. 3, pp. 103 - 112. ISSN 1804-1930, DOI 10.7160/aol.2016.080310.

\section{Introduction}

Mountains constitute the ecological backbone of Europe, providing essential ecosystem services (Bernués et al., 2014). These ecosystem services include a provisioning function (agricultural production, production of timber, game, berries, mushrooms, fresh water, etc.), a regulating function (carbon sequestration, hydrological protection, etc.), and a cultural function (recreation, aesthetics, spiritual benefits) (Považan et al., 2014; Häyhä et al., 2015; Bernués et al., 2014). Palleto et al. (2015) add a habitat function, reclassifying the supporting services function (plant production, animal production, gene pool protection, nutrition cycling).

Farming activities are a key factor in shaping the mountain landscape (Lefebvre et al., 2012). Society benefits from agricultural landscapes in many ways. The benefits of landscape can be seen as having three components: landscape value (scenic), recreational value, and nostalgic value (Gioi et al., 2007). Notaro and Paletto (2011) point out that the natural environment in mountain areas predominantly consists of forests and meadows, which provide an important resource for the socioeconomic development of mountain areas.

The environmental assets of mountain landscapes generated through agricultural land management have the characteristic of agro-environmental public goods - non-rival, non-excludable goods, demanded by society, whose supply can be increased by farming activity (Burrell, 2011). Ciaiac and Gomez y Poloma (2011) also noted that landscape is one of the key public goods produced by agriculture. Due to their specific characteristics, a market for these goods does not exist and policy measures are needed to ensure delivery. Notable policy measures which contribute to the provision of valuable landscapes and their associated assets include environmental and Less-Favoured Areas (LFA) payments. However, these supports often do not reflect the value of such an environment. This is supported by Bernués et al. (2014), who found that the total economic value of the mountain agro-ecosystem is three times higher than the current level of support for agro-environmental policies. 
Valuation of mountain landscapes and ecosystems

Environmental services and landscape goods are rarely incorporated into the economic valuation of natural resources, even though they form a large portion of the total economic value (Molina et al., 2016). Bernués et al. (2014) add that economic valuation is highly controversial. A non-material good is considered by many to be incommensurable, and therefore economic valuation is assumed to be a driver for the commodification of nature and very difficult to apply to certain ecosystems. Tagliafierro et al. (2013) stress that determining monetary value is not easy due to individual preferences regarding landscapes. Knudsen et al. (1995) add that a landscape cannot be the same for two individuals, because each of them has a different interaction with the landscape and their knowledge of the landscape differs. Soliva and Hunzinker (2009) explain landscape preferences using psychological, biological and aesthetic approaches. RodriguezOrtega et al. (2014) found that the willingness to pay for mountain ecosystems differs from 88 EUR to 334 EUR, according to psychographic profile, demonstrating individual preferences and valuations of landscapes and ecosystems.

A literature survey proves that studies valuating ecosystems or landscapes use both market and non-market valuation methods. Market valuation is normally used for assessing the provisioning services of ecosystems and includes, for example, the market price of timber or livestock (Paletto et al., 2015; Hÿahä et al.; 2015; Považan et al., 2014). The regulating services of ecosystems are usually valued through non-market methods. Paletto et al. (2015) use the replacing cost method and voluntary price; Hÿahä et al. (2015) use carbon price and the cost of bioengineering technologies to assess hydrological and carbon protection as a part of protection services. The cultural services of ecosystem are predominantly valuated through non-market methods, namely stated preferences methods. Similarly, landscape is evaluated mainly by non-market, especially stated preferences, methods, including willingness to pay (further WTP) and choice experiment (CE). Exceptions include the travel cost approach (Melichar, 2007; Gluck and Kuen, 1997) and hedonic pricing (Lutting, 2000; Van Huylenbroeck et al., 2006). Studies using stated preferences methods usually apply WTP (Sayadi et al., 2009; Kubickova, 2004; Bastien et al., 2015, Notaro and Palleto, 2011; Antouskova,
2012) or choice experiment (Campbell et al., 2015; Bernués et al., 2014; Molina et al., 2016).

Addressing this issue, the paper aims to evaluate the contribution of agriculture to the value of European mountain landscapes and ecosystems, and to explain the differences in the values. The paper should answer the following research questions: What is the average value of mountain landscapes/ecosystems in Europe? How is this value covered by environmental and LFA subsidies? Does this value differ based on the position of agriculture in the national economy of the analysed countries? Are the differences connected with the share of agricultural land in less-favoured areas and with the share of LFA payments in the total subsidy payment? How is this value determined by the valuation technique? Are there differences in this value for visitors and residents?

The rest of the paper is organized as follows. First, we introduce the methods and data we used. We then present the main characteristics of the analysed studies and the results of our analysis. Finally, we discuss the results and provide concluding remarks.

\section{Materials and methods}

The aims of the paper are reached through metaanalysis, which uses empirical estimates of some indicators from several studies and attempts to explain the variation in these estimates, based on differences across studies, as explanatory variables in a regression model (Thiam et al., 2001).

We focus on 22 studies that evaluated the value of mountain landscape/ecosystem in European countries. Empirical studies focusing on mountain landscapes and ecosystems were retrieved from the Scopus, ISI Web of Science, and ScienceDirect databases. Keywords for searching were: mountain and landscape (or ecosystem), and valuation (or value, evaluation or appreciation). In addition, a snowball method was used to find the required studies. Subsequently, the found studies were selected according to the area studied, and only those dealing with European mountains were analysed.

First we described these studies, and then compared the estimated values of the mountain landscapes/ ecosystems, measured in EUR per hectare, to the amount of environmental and LFA payments drawn by the average farm in less-favoured mountain areas per hectare, according to the Farm Accountancy Data Network (FADN). 
Secondly, we formulated a regression model based on the studies and measured the value in EUR per person. The basic hypothesis of this research was that the variation in mountain landscape/ ecosystem value reported in these studies can be explained by attributes of the studies such as evaluation technique, respondent specification (visitor/resident), position of agriculture in the national economy, and the localization of agriculture in mountain LFA (Alvarez-Farizo et. al., 1999; Maragon and Visintin, 2007; Ciaian and Gomez y Paloma, 2011). We also supposed that the differences in the value of mountain landscapes/ ecosystems result from agricultural policy (Moon and Griffith, 2010), namely from the significance of LFA payments in the total subsidy scheme of farms. That is, the following model was estimated:

value $=f(A S, L F A M S, L F A P S, D V I S, D T C, D C E)$

where value is a landscape/ecosystem value measured in EUR per person (visitor or resident) per day, AS is the share of agriculture in total gross value added (GVA) retrieved from the Eurostat database, DVIS is a dummy variable for the value for visitors, LFAMS is the share of less-favoured mountain areas in the total utilized agricultural area, retrieved from the Eurostat database, LFAPS is the share of LFA subsidies in total subsidies, excluding subsidies on investments gained by an average farm located in a mountain area according to FADN, DTC is a dummy for the travel cost method, and DCE is a dummy for choice experiment.

Most analysed studies present a range of mountain landscape/ecosystem values. We used averages of this range as the value of the dependent variable.

The model was estimated in linear form by the ordinary least square procedure using the econometric software LIMDEP version 9.0. Homoscedasticity was tested by the Breusch-Pagan test, and heteroscedasticity was solved by White's heteroscedasticity-consistent standard errors estimator (Green, 2008).

\section{Results and discussion}

The main characteristics of the analysed studies are presented in a Table 1.

Out of 22 studies focused on the value of mountain landscapes/ecosystems, 17 studies measured the value per person and six studies analysed the value per hectare. These six studies were removed from the base of the regression model and described separately. Of these six studies, two were focused on the Alps in Italy, namely Trentino and Fiemme, Fassa, one on the Alps in Austria (Leiblachtal), one on the Alps in Switzerland (Davos), one on Velká Fatra in Slovakia, and one on Tatra in Poland. All of these studies used the market approach, contingent valuation method and replacement costs. The value of the mountain landscape/ecosystem ranged from 5 EUR per hectare per year to 22,596 EUR per hectare per year. The maximum value was achieved in the Polish part of Tatra. The minimum occurred in the Italian Alps (Fiemme, Fassa) as the price for cultural services. The average value was 3,068 EUR per hectare per year. However, the mountain landscape/ecosystem value was lower in the Alps in Italy and Austria than in the mountains of Slovakia and Poland. That is, the value is higher in countries with lower GDP.

Measurement of the value in EUR per hectare enables a comparison of the landscape/ecosystem value and the policy support for farming in these areas. This is presented in Table 2 .

It is obvious that the agricultural policy support (namely environmental (ES) and LFA subsidies) for farming in mountain areas covered less than $30 \%$ of the landscape/ecosystem value. Taking into account that the value was determined by the replacement cost method, we can conclude that public support is insufficient to cover the costs for landscape services performed by farmers. Bernués et al. (2014) also present similar results. On the other hand, Ciaian and Paloma y Gomez (2011) took into account total CAP supports and, on the basis of meta-analysis of agricultural landscape valuation studies, found that the value of agricultural landscapes (142 EUR per hectare) is smaller than the CAP support level (270 EUR per hectare).

The remaining 17 studies represent the basis of the meta-analysis. These studies can be characterized by a dominant focus on the value for residents (11 studies), determined by willingness to pay. Three studies also used choice experiment, and two studies preferred the travel cost technique. The majority of the studies were focused on Central European countries - seven studies. Southern European countries were represented by six studies, and there was also one case of a Western European country. Seven studies were focused on the landscape/ecosystem in countries where GDP per capita was higher than the EU average -28 . 


\begin{tabular}{|c|c|c|c|c|}
\hline Study & Country & Mountain & Method & Value \\
\hline \multirow[t]{3}{*}{ Bastian et al. (2015) } & Germany & $\begin{array}{l}\text { Ore Mountains (Sachsische } \\
\text { Sweiz-Ostrzbiege) }\end{array}$ & $\begin{array}{l}\text { WTP for natural conservation } \\
\text { and landscape management }\end{array}$ & $\begin{array}{l}0.75-1.36 € / \text { guest } / \text { night by tourist service } \\
\text { provider }\end{array}$ \\
\hline & & & & $1.06-2.73 € /$ day by visitors \\
\hline & & & & 5.03-18.91€/residents/year \\
\hline \multirow[t]{2}{*}{ Bernués et al. (2014) } & Spain & $\begin{array}{l}\text { Mediterranean mountains } \\
\text { (Sierra y Canones de Guara) }\end{array}$ & WTP/CE & $198.8 € /$ person/year for general public \\
\hline & & & Annual tax & $121.2 € /$ person/year for locals \\
\hline \multirow[t]{2}{*}{ Molina et al. (2016) } & Spain & Sierra Morena massif (Huelva) & WTP/CE & $9.25 € /$ person as entrance fee \\
\hline & & & & landscape - type $5-4.21-25.84 €$ \\
\hline Kubickova (2004) & Czech Republic & Bile Karpaty & $\begin{array}{l}\text { WTP for provisioning agricultural- } \\
\text { landscape cultivation services }\end{array}$ & $261.21 \mathrm{CZK} /$ person/year \\
\hline Campbell et al. (2005) & Ireland & & $\mathrm{CE}$ & 45.18-92.63€/person/year \\
\hline $\begin{array}{l}\text { Tempesta and Thiene } \\
(2004)\end{array}$ & Italy & Cortina D`Ampeyyo & $\begin{array}{l}\text { WTP for conservation of mountain } \\
\text { meadows }\end{array}$ & $3.25 € /$ year/person \\
\hline Getzner (2000) & Austria & $\begin{array}{l}\text { Alps (Hohe Tauern National } \\
\text { Park (NP)) }\end{array}$ & WTP & $7 € /$ visitor /visit \\
\hline $\begin{array}{l}\text { Gluck and Kuen } \\
\text { (1977) }\end{array}$ & Austria & Alps (Grosser Ahornboden) & $\mathrm{TC}$ & $5 € /$ visitor/visit \\
\hline $\begin{array}{l}\text { Hackl and Pruckener } \\
\text { (1997) }\end{array}$ & Austria & Alps (Kalkalpen NP) & WTP & $10-30 € /$ resident/year; 8-13/visitor/year \\
\hline Gios et al. (2006) & Italy & Alps (Campogrosso) & WTP & $5 € /$ resident/visit \\
\hline Lowenstain (1995) & Germany & Alps (Hinterstein) & WTP & $48 € /$ resident \\
\hline $\begin{array}{l}\text { Notaro and Paletto } \\
\text { (2011) }\end{array}$ & Italy & Alps (Premena) & WTP donation for maintaining LS & $94 € /$ year \\
\hline Antouskova (2012) & Czech Republic & Sumava mountains & WTP & $100 \mathrm{CZK} /$ visitor/visit \\
\hline Sayadi et al. (2009) & Spain & Alpujarran & $\begin{array}{l}\text { WTP for a day of lodging } \\
\text { to enjoy different views presented } \\
\text { in photographs }\end{array}$ & $\begin{array}{l}27.07 € / \text { day is the average price to enjoy view } \\
\text { of the landscape }\end{array}$ \\
\hline \multirow[t]{4}{*}{ Füzyová et al. (2009) } & Slovakia & Tatra NP & WTP for environment & Visitors: Mean for entrance fee 54.12 SKK \\
\hline & & & & For better environment $329.71 \mathrm{SKK}$ \\
\hline & & & & Residents for environment: 645.40 SKK \\
\hline & & & & Entrepreneurs for environment: $1,043.75 \mathrm{SKK}$ \\
\hline Melichar (2007) & Czech Republic & Jizerske mountains & $\mathrm{TC}$ & $\begin{array}{l}\text { Consumer surplus: } 18 \text { USD Poisson model, } \\
17 \text { USD truncated Poisson, } 56 \text { USD truncated } \\
\text { negative Binomial }\end{array}$ \\
\hline \multirow{3}{*}{$\begin{array}{l}\text { Gret-Regamey et al. } \\
(2008)\end{array}$} & Switzerland & Alps (Davos) & Gret-Regamey et al. (2007) & Scenic beauty, $24,000 €$ \\
\hline & & & & $\begin{array}{l}\text { per ha per year; habitat, } 2 € / \text { ha/year; carbon } \\
\text { sequestration: } 3,100 € / \text { ha/year; }\end{array}$ \\
\hline & & & & avalanche protection: $64,700 € /$ ha/year \\
\hline Goio et al. (2008) & Italy & Alps (Trentino) & $\begin{array}{l}\text { Market approach (MA), CVM, } \\
\text { replacement costs (RC) }\end{array}$ & $392.08 € / \mathrm{ha}$ \\
\hline \multirow[t]{3}{*}{ Paletto et al. (2015) } & Austria & Alps (Leiblachtal) & MA, CVM, RC & $200-1,400 € /$ ha/year (provisioning services) \\
\hline & & & & $10-760 € /$ ha/year (regulating services) \\
\hline & & & & $5-60 € /$ ha/year (cultural services) \\
\hline \multirow[t]{2}{*}{ Häyhä et al. (2015) } & Italy & Alps (Fiemme, Fassa) & MA, CVM, RC & $820 € /$ ha/year \\
\hline & & & & $\begin{array}{l}\text { (provisioning services } 40 \% \text {, regulating services } \\
49 \% \text {, cultural services } 11 \% \text { ) }\end{array}$ \\
\hline Považan et al. (2014) & Slovakia & Velká Fatra & MA, CVM, RC & $4,437 € /$ ha/year \\
\hline Getzner(2010) & Poland & Tatra NP & MA, CVM, RC & $22,596 € /$ ha/year \\
\hline
\end{tabular}

Source: Own calculations

Table 1: Analysed studies. 


\begin{tabular}{lccccc}
\hline Country & $\begin{array}{c}\text { Value } \\
\text { [EUR/ha] }\end{array}$ & $\begin{array}{c}\text { Environmental subsidies } \\
\text { [EUR/ha] }\end{array}$ & $\begin{array}{c}\text { ES/Value } \\
{[\%]}\end{array}$ & $\begin{array}{c}\text { LFA payment } \\
\text { [EUR/ha] }\end{array}$ & $\begin{array}{c}\text { LFA/Value } \\
\text { [\%] }\end{array}$ \\
\hline Italy & 606 & 29.25 & 4.83 & 25.76 & 4.25 \\
Austria & 1,218 & 198.22 & 16.27 & 135.32 & 11.11 \\
Poland & 22,596 & 70.96 & 0.31 & 48.25 & 0.21 \\
Slovakia & 4,437 & 131.03 & 2.95 & 79.41 & 1.79 \\
\hline
\end{tabular}

Source: FADN, Own calculations

Table 2: Comparison of landscape/ecosystem value and subsidies.

The average value of mountain landscape/ecosystem ranged from 0.01 to 27.07 EUR per person per day. The highest value was achieved in Alpujarran in Spain by WTP, and represented the price to enjoy a view of the landscape. On the other hand, the lowest value occurred in Cortina D'Ampezzo in Italy by WTP, as the price for conservation of mountain meadows. The mean value was 3.91 EUR per person per day. However, the standard deviation (6.81) shows that the differences between the values presented in the analysed studies are huge. These differences are presented in Table 3 according to the specific characteristics of the studies.

\begin{tabular}{lcc}
\hline Category & $\begin{array}{c}\text { Mean value } \\
\text { [EUR / day] }\end{array}$ & $\begin{array}{c}\text { Standard } \\
\text { deviation }\end{array}$ \\
\hline $\begin{array}{l}\text { Share of agriculture in GVA under EU } \\
\text { average }\end{array}$ & 2.02 & 2.86 \\
$\begin{array}{l}\text { Share of agriculture in GVA above EU } \\
\text { average }\end{array}$ & 4.92 & 8.13 \\
$\begin{array}{l}\text { Share of UAA in LFA-mountain } \\
\text { under EU average }\end{array}$ & 3.1 & 5.74 \\
$\begin{array}{l}\text { Share of UAA in LFA-mountain } \\
\text { above EU average }\end{array}$ & 4.34 & 7.51 \\
$\begin{array}{l}\text { Share of LFA payment in total } \\
\text { subsidies under EU average }\end{array}$ & 5.33 & 9.38 \\
$\begin{array}{l}\text { Share of LFA payment in total } \\
\text { subsidies above EU average }\end{array}$ & 2.95 & 4.65 \\
Resident & 4.07 & 8.56 \\
Visitor & 3.65 & 3.24 \\
Willingness to Pay & 3.36 & 7.59 \\
Choice Experiment & 2.58 & 4.45 \\
Travel Cost & 10.37 & 7.59 \\
Country in Central Europe & 2.95 & 4.65 \\
Country in Southern Europe & 6.07 & 9.89 \\
Country in Western Europe & 0.19 & $\mathrm{NA}$ \\
GDP under EU average & 4.37 & 8.07 \\
GDP above EU average & 3.34 & 5.3 \\
\hline & & \\
\hline & & \\
\hline
\end{tabular}

Note: GVA means total gross value added, UAA means utilized agricultural land, LFA means less-favoured area,

NA means not-available due to the sample having only one case.

Source: Own calculations

Table 3: Basic characteristics of mountain landscape/ecosystem value in different categories.

Table 3 shows that higher values of mountain landscape/ecosystem were achieved in countries where the contribution of agriculture to the total gross value added is above average. We can also observe that the mountain landscape/ecosystem value is higher on average in countries where agricultural land is more often located in a lessfavoured area. However, it seems that this higher value is not a consequence of LFA subsidies, because the mountain landscape/ecosystem value is lower in countries where LFA payments represent a more significant part of the total subsidy structure for a typical farm. A majority of the analysed studies distinguished between the value for visitors and the value for residents. The descriptive statistics show that residents were willing to pay a slightly higher price than visitors for a more attractive landscape and a higher quality of ecosystems. When focused on the method of valuation, it is obvious that a significantly higher value was obtained when the travel cost technique was employed.

The figures in Table 3 suggest that a higher mean value for mountain landscape/ecosystem was achieved in countries with lower wealth, measured by GDP per capita, than in countries where GDP was higher that the EU average of 28. That negates the assumption that people in wealthier countries are willing to pay a higher price for an attractive landscape, which was based on the findings of Ciaian and Gomez y Paloma (2011). The value of mountain landscape/ecosystem was also assessed higher in countries located in Southern Europe and on the basis of the travel cost technique. A connection can be seen between the position of tourism in the economies of European states. People in countries with a higher share of tourism in GDP appreciate landscape/ ecosystem more than people in strongly industrial or financial countries.

A detailed analysis of the main determinant of mountain landscape/ecosystem value in connection with agriculture and the Common Agriculture Policy is based on a regression model, described in equation (1). Table 4 shows that the majority of parameters in this model are statistically significant, at least at the $10 \%$ level of significance. Because the model used dummy 


\begin{tabular}{lccc}
\hline Variable & Coefficient & Standard error & Prob. $|\mathbf{t}|>\mathbf{T}^{*}$ \\
\hline Constant & 4.7671 & 3.3947 & 0.1837 \\
DVIS & $3.2557^{* *}$ & 1.5069 & 0.05 \\
DTC & $8.8047^{* *}$ & 3.1763 & 0.0159 \\
DCE & $-12.3178^{*}$ & 6.9364 & 0.0992 \\
AS & $0.0478^{* *}$ & 0.0214 & 0.0436 \\
LFAMS & -0.0561 & 0.0473 & 0.2571 \\
LFAPS & $-0.5254^{*}$ & 0.2864 & 0.0895 \\
R-square & 0.447 & & \\
Breusch-Pagan & 21.13 & & 0.0017 \\
\hline
\end{tabular}

Note: $* * *, * *$, and $*$ denote significance at the $1 \%, 5 \%$, and $10 \%$ levels, respectively

Source: Own calculations

Table 4: Model estimates.

variables, the intercept represents the mean value of mountain landscape/ecosystem for residents based on the willingness-to-pay method. When we employ a dummy variable for visitors, we can conclude that the value for visitors is higher on average by $3.26 \mathrm{EUR}$, ceteris paribus. The parameter of the travel cost technique shows that this method leads to a higher value that WTP, specifically by 8.81 EUR on average in the case of resident value, ceteris paribus. On the other hand, choice experiment yields a lower value, specifically by 12.32 EUR on average in the case of value for residents, ceteris paribus. That is, the WTP seems to be a more appropriate evaluation technique, as it leads to a value in the middle of the extremes achieved using other techniques.

Considering the role of agriculture, it is obvious that a stronger position of agriculture in the national economy, measured by the share of agriculture in gross value added, leads to a higher value of the landscape/ecosystem. Because the share of agriculture in GVA is employed in the model in percentage form, we can conclude that an increase in this share of one percentage point is connected with an increase in the value by 0.05 EUR per person per day. That is, the landscape/ecosystem has a higher value in countries where land is a more important resource for the economy. Based on this result, we can conclude that the landscape/ ecosystem value will be higher in countries such as Bulgaria, Romania, Hungary, Croatia, Greece, Estonia, Lithuania and Latvia, where the share of agriculture in gross value added is more than $3.3 \%$. On the other hand, the landscape/ecosystem in countries whose share of agriculture in gross value added is under $1 \%$ will be assessed a lower price. Belgium, Luxembourg and the United Kingdom are examples of such countries.
The parameter of proportion of farming in less-favoured mountain areas in national agriculture is not statistically significant. Table 5 shows this proportion, measured by the share of agricultural land in mountain and other LFA in the total utilized agricultural area (UAA) of the analysed countries. It is obvious that there is no unequivocal relationship between the share of LFA and the value of mountain landscape/ecosystem. This could help explain the non-significant result.

Table 5 also presents the share of LFA payments in the sum of subsidies (excluding subsidies on investments) gained by the average farm operating in mountain LFA in the analysed countries. However, no unequivocal relationship could be seen between this share and the value of mountain landscape/ecosystem; the parameter that measures the influence of LFA subsidies is statistically significant at the $10 \%$ level and proves that the one-percent increase in the share of LFA payments in the total sum of subsidies of a typical farm is connected with a decrease in the landscape/ ecosystem value by 0.53 EUR, ceteris paribus. That is, a higher value is supposed in countries such as Bulgaria, Spain and Romania, where the share is under $10 \%$. On the other hand, we can suppose that the mountain landscape/ecosystem value will be assessed lower in France, Portugal, Finland and Slovenia, where the share of LFA subsidy is higher than $20 \%$.

Arriaza et al. (2004) explained this negative effect of LFA payments - maintenance in the production of land of poor agricultural quality, as an alternative to natural vegetation, decreases the perception of wilderness in the landscape, and thus its beauty. On the other hand, Lefebvre et al. (2012) mentioned 


\begin{tabular}{lcccc}
\hline Country & $\begin{array}{c}\text { Mountain LFA } \\
{[\%]}\end{array}$ & $\begin{array}{c}\text { Other LFA } \\
{[\%]}\end{array}$ & $\begin{array}{c}\text { LFA subsidy share } \\
{[\%]}\end{array}$ & $\begin{array}{c}\text { Landscape/Ecosystem } \\
\text { Value [EUR/day] }\end{array}$ \\
\hline Czech Republic & 17.8 & 36.06 & 23.9 & 6.49 \\
Germany & 1.84 & 53.52 & 18.73 & 0.69 \\
Ireland & 0 & 74.14 & 0 & 0.19 \\
Spain & 29.71 & 58.32 & 4.66 & 9.3 \\
Italy & 33.75 & 23.33 & 8.76 & 1.76 \\
Austria & 54.71 & 18.89 & 22.21 & 3.02 \\
Slovakia & 34.32 & 41.37 & 32.8 & 0.92 \\
\hline
\end{tabular}

Source: Own calculations

Table 5: Proportion of mountain and other LFA, shares of LFA subsidies in total subsidies and mean value of mountain landscape/ecosystem in the analysed countries.

that abandoning production in marginal areas can have a negative influence on landscape because of the homogenisation effect.

\section{Conclusion}

Agricultural land management strongly shapes mountain landscape, which is considered a public good, per se (for its aesthetic, recreational and cultural value), but also provides the ecological infrastructure necessary for the existence of other public goods such as biodiversity, water and soil quality. The importance of delivering such public goods has been recognized by the public policy of European countries. Environmental and LFA payments are the most significant examples of Common Agriculture Policy measures which target the support of this delivery of public goods. However, there are studies which have declared that these supports do not reflect the value of such environments (e.g. Bernués et al., 2014). To set the right level of subsidies, it is important to find out the value of the landscape/ecosystem and evaluate the factors which led to differences in this value.

According to the meta-analysis of 22 mountain landscape or ecosystem valuation studies, we can conclude that the average value of a European mountain landscape/ecosystem is 3.91 EUR per person per day. However, there are regions with significantly higher values - Alpujarran in Spain. The research questions were especially focused on the differences in the mountain landscape/ecosystem value due to farming and agricultural policy, and we can conclude that the mountain landscape/ecosystem is assessed higher in countries where agriculture has a stronger position in the national economy and where the land is a more important resource for the economy. Bulgaria, Romania, Hungary,
Croatia, Greece, Estonia, Lithuania, Latvia and Slovakia are examples of these countries in Europe.

Because mountain areas are usually characterized as less-favoured areas, our research also tried to find out whether the differences in landscape/ecosystem value are connected with the share of agricultural land in less-favoured areas in total agricultural area, and with the share of LFA payments in total subsidies. From this point of view, we can conclude that no unequivocal relationship was demonstrated between the share of land in LFA and the value of mountain landscape/ecosystem. On the other hand, the regression analysis brought a significant result, namely that the higher share of LFA subsidies in the total sum of subsidies (excluding subsidies in investments) of the average farm located in less-favoured mountain areas is connected with the lower value of mountain landscape/ ecosystem. France, Portugal, Finland and Slovenia are examples of countries where LFA subsidies are an important part of the income of the average farm drawn from agricultural policy. Furthermore, we can conclude that the public support represented by LFA and environmental payments is insufficient to cover the cost of landscape services provided by farmers.

We also analysed the effect of the valuation technique on landscape/ecosystem value and the differences in this value for visitors and residents. Our conclusion is that the WTP is the most appropriate evaluation technique, as it leads to a value in the middle of the extremes acquired using other techniques. Moreover, the regression model showed that visitors are willing to pay a higher price for mountain landscapes and the quality of mountain ecosystems than residents. 


\section{Acknowledgements}

Pieces of knowledge introduced in this paper resulted from the solution of the research project QJ1530286 "Optimization of the subsidy system for agricultural producers with regard to the production of public goods" financed by NAZV within the research program: Complex sustainable systems in agriculture $2012-2018$ "KUS".

Corresponding author:

Ing. Michaela Havliková, Ph.D.

Department of Economics, Faculty of Economics and Management,

Czech University of Life Sciences Prague, Kamýcká 129, Prague 6, 165 21, Czech Republic

Phone:+420224382338,E-mail: havlikovam@pef.czu.cz

\section{References}

[1] Alvarez-Farizo, B., N. Hanley, R.E. Wright and D. Macmillan (1999) "Estimationg the Benefits of Agri-environmental Policy: Econometric Issue in Open-ended Contingent Valuation Studies", Journal of Environmental Planning and Management, Vol. 42, No. 1, pp. 23-43. ISSN 0964-0568. DOI 10.1080/09640569911280.

[2] Antoušková, M. (2012) "Economic value of recreation - Determinants influencing the willingness to pay in natural region with low-intensity agriculture", Agris on-line Papers in Economics and Informatics, Vol. 4, No. 4, pp. 3 - 9. ISSN 1804-1930.

[3] Arriaza, M., J. F. Cañas-Ortega, et al. (2004) "Assessing the visual quality of rural landscapes", Landscape and Urban Planning, Vol. 69, pp. 115-125. ISSN 0169-2046. DOI 10.1016/j.landurbplan.2003.10.029.

[4] Bastian, O., Ch. Stein, G. Lupp, J. Behrens, Ch. Renner, and K. Grunewal (2015) "The appreciation of nature and landscape by tourism service provides and visitors in the Ore Mountains (Germany)", Landscape online, Vol. 41, pp. 1 - 23. ISSN 1865-1542. DOI 10.3097/LO.201541.

[5] Bernués, A., Rodriguez-Ortega, T., Ripoll-Bosh, R. and Alfnes, F. (2014) "Socio-cultural economic valuation of ecosystem services provided by Mediterranean mountain agroecosystem", PLoS ONE, Vol. 9, No. 7, pp. e102479. ISSN 1932-6203. DOI: 10.1371/journal.pone.0102479.

[6] Burrel, A. (2011) „Evaluating Policies for Delivering Agri-environmental Public Goods“, paper presented on OECD Workshop on the Evaluation of Agri-environmental Policies, Braunschweig, 20-22.6.2011.

[7] Campbell, D., Hutchinson, G. and Scarpa, R. (2005) "Using choice experiment to value farm landscape improvements: Implications of inconsistent preferences", Applied Environmental Economics Conference. [Online]. Available: https://www.researchgate.net/publication/237522629_ USING_CHOICE_EXPERIMENTS_TO_VALUE_FARM_LANDSCAPE_IMPROVEMENTS_ IMPLICATIONS_OF_INCONSISTENT_PREFERENCES. [Accessed: 15 Jun. 2016].

[8] Ciaian, P., Gomez y Paloma, S. (2011) „The Value of EU Agricultural Landscape“, Paper presented at the Agricultural \& Applied Economics Association's 2011 AAEA \& NAREA Joint Annual Meeting, Pittsburg, Pensylvania, July 24-26, 2011. DOI 10.2791/60382

[9] Füzyová, L., Lániková, D. and Novorlský, M. (2009) "Economic Valuation of Tatras National Park and Regional Environmental Policy", Polish Journal of Environmental Studies, Vol 18, No. 5, pp. $811-818$. ISSN 1230-1485.

[10] Getzner M. (2000) "Hypothetical and real economic commitments, and social status in valuing a species protection program", Journal of Environmental Planning and Management, Vol. 43, No. 3, pp. 541 - 559. ISSN 1360-0559. DOI 10.1080/713676576.

[11] Getzner, M. (2010) "Ecosystem services, financing, and the regional economy: A case study from Tatra national Park, Poland", Biodiversity, Vol. 11, No. 1-2, pp. 55 - 61. ISSN 2160-0651. DOI 10.1080/14888386.2010.9712648 
[12] Gios G., Goio I., Notaro S. and Raffaelli R. (2006) "The value of natural resources for tourism: A case study of the Italian Alps", International Journal of Tourism Research, Vol. 8, No. 2, pp. 77 - 85. ISSN 1522-1970. DOI 10.1002/jtr.552.

[13] Glück P. and Kuen H. (1977) “Der Erholungswert des Grossen Ahornbodens" [in German]. Allgemeine Forstzeitung, Vol. 88, pp.7 - 11. ISSN 0002-5879.

[14] Goio I., Gios, G. and Pollini C. (2008) "The development of forest accounting in the province of Trento (Italy)", Journal of Forest Economics, Vol. 14, No. 3, pp. 177 - 196. ISSN 1104-6899. DOI 10.1016/j.jfe.2007.09.002.

[15] Green, W. H. (2008) "Econometric Analysis", Sixth edition. Upper Saddle River, New Jersey: Pearson Education. 1178 p. ISBN 978-0-13-513740-6.

[16] Grêt-Regamey A, Bebi P, Bishop I. D, Schmid W. (2008) "Linking GIS-based models to value ecosystem services in an Alpine region", Journal of Environmental Management, Vol. 89, No. 3, pp. 197-208. ISSN 0301-4797. DOI 10.1016/j.jenvman.2007.05.019.

[17] Häyhä, T., Franzese, P. P., Palleto, A. and Fath, B. D. (2015) “Assessing, valuing and mapping ecosystem services in Alpine forest”, Ecosystem Services, Vol. 14, pp. 12 - 23. ISSN 2212-0416. DOI 10.1016/j.ecoser.2015.03.001.

[18] Hackl, F. and Pruckner G. J. (1997) “Contingent Valuation als Instrument zur ökonomischen Bewertung der Landschaft [in German]." Frankfurt am Main, Germany: Lang. ISBN 978-3631305379.

[19] Knudsen D. C., Metro-Roland, M. M., Soper, A. K. and Greer Ch. E. (1995) “Landscape, tourism, and meaning". Ashgate Publishing Ltd., Hampshire. ISBN 978-0-7546-49-3.

[20] Kubíčková, S. (2004) "Non-market evaluation of landscape function of agriculture in the PLA White Carpathians", Agricultural Economics, Vol. 50, No. 9, pp. 399 - 393. ISSN 1805-9295.

[21] Lefebvre, M., Espiroza, M., Gomez y Poloma, S. (2012) "The influence of the Common Agricultural Policy on agricultural landscapes", Luxembourg: Publications Office of the European Union, 2012. ISBN 978-92-79-25828-2.

[22] Löwenstein W. (1995) "Die monetäre Bewertung der Schutzfunktion des Waldes vor Lawinen und Rutschungen in Hinterstein (Allgäu) [in German]" , In: Bergen V, Löwenstein W, Pfister G. Studien zur monetären Bewertung von externen Effekten der Forst- und Holzwirtschaft. Schriften zur Forstökonomie 2. $2^{\text {nd }}$ edition. Frankfurt am Main, Germany: Sauerländer, pp 117-178.

[23] Lutting, J. (2000) "The value of trees, water and open space as reflected by house price in Netherlands", Landscape and Urban Planning, Vol. 48, No. 3-4, pp. 161 - 167. ISSN 0169-2046. DOI 10.1016/S0169-2046(00)00039-6.

[24] Marangon, F. and F. Visintin (2007) "Rural landscape valuation in a cross-border region", Cahiers d'économie et sociologie rurales, Vol. 84, pp. 113-132. ISSN 0755-9208.

[25] Melichar, J. (2007) "Economic valuation of forest quality change in Jizerské Hory mountains: The evidence from contingent behavior study", Paper presented at the Ninth Annoual Bioecon Conference, Kings College Cambridge. [Online]. Available: http://www.bioecon-network.org/ pages/9th_2007/Melichar.pdf. [Accessed: 15 Jun. 2016].

[26] Molina, J. R., Silva, F. R. and Herrera, M. A. (2016) "Integrating economic landscape valuation into Mediterranean territorial planning", Environmental Science \& Policy, Vol. 56, pp. 120 - 128. ISSN 1462-9011. DOI: 10.1016/j.envsci.2015.11.010

[27] Moon, W. and W. Griffith (2010) „Assessing public preferences and holistic economic value for multifunctional agriculture in the U.S.“ Paper presented et 2010 Annual Meeting, Orlando, Florida. [Online]. Available: http://ageconsearch.umn.edu/bitstream/56010/2/Wanki_Moon manuscript_SouthernAgEconMeeting_Dec24_2009.pdf. [Accessed: 15 Jun. 2016].

[28] Notaro, S. and Paletto, A. (2011) "Links between Mountain Communities and Environmental Services in the Italian Alps", Sociologia Ruralis, Vol. 51, No. 2, pp. 137 - 156. ISSN 1467-9523. DOI 10.1111/j.1467-9523.2011.00532.x. 
[29] Palleto A., Geitner, C., Grilli, G., Hastik, R., Pastorella, F. and Rodrigez Garcia, L. (2015) "Mapping the value of ecosystem services: A case study from the Austrian Alps", Annals of Forest Research, Vol. 58, No. 1, pp. 157 - 175. ISSN 1610-7403. DOI 10.15287/afr.2015.335

[30] Považan, R., Getzner, M. and Švajda, J. (2014) "Value of ecosystem services in mountain national parks. Case study of Vel'ká Fatra National park (Slovakia)", Polish Journal of Environmental Studies, Vol 23, No. 5, pp. 1699 - 1710. ISSN 1230-1485.

[31] Rodriguez-Ortega, T., Bernués, A. and Alnes, F. (2016) "Psychographic profile affects willingness to pay for ecosystem services provided by Mediterranean high nature value farmland", Ecological Economic, Vol. 128, pp. 232 - 245. ISSN 0921-8009. DOI 10.1016/j.ecolecon.2016.05.002.

[32] Sayadi, S., González-Roa C. M. and Calatrava-Raquena, J. (2009) "Public preferences for landscape features: The case of agricultural landscape in mountainous Mediterranean areas", Land Use Policy, Vol. 26, No. 2, pp. 334 - 344. ISSN 0264-8377. DOI 10.1016/j.landusepol.2008.04.003.

[33] Soliva, R. and Hunziker, M. (2009) "How do biodiversity and conservation values relates to landscape preferences? A case study from the Swiss Alps", Biodiversity and Conservation, Vol. 18, No. 9, pp. 2483 - 2507. ISSN 1572-9710.

[34] Tagliafierro, C., Longo, A., Eetvelde, V., Antrop, M. and Hutchinson, W. G. (2013) "Landscape economic valuation by integrating landscape ecology into landscape economics", Environmental Science \& Policy, Vol. 32, pp. 26 - 36. ISSN 1462-9011.

[35] Tempesta, T. and Thiene, M. (2004) “The willingness to pay for conservation of mountain landscape in Cortina d'Ampezzo", Proceeding of the $90^{\text {th }}$ EAAE Seminar, Multifunctional Agriculture, Rennes, France. [Online]. Available: https://www.researchgate.net/publication/237115492_The willingness_to_pay_for_the_conservation_of_mountain_landscape_in_Cortina_D'Ampezzo_Italy. [Accessed: 15 Jun. 2016].

[36] Thiam, A., Bravo-Ureta, B. E., Rivas, T. E. (2001) "Technical Efficiency in Developing Countries Agriculture: A Meta-Analysis", Agricultural Economics, Vol. 25, pp. 235- 243. ISSN 1805-9295. DOI 10.1111/j.1574-0862.2001.tb00204.x.

[37] Van Huylenbroeck, G., Vanslembrouck, I., Calus, M and Van De Vaide, L. (2006) "The influence of planned-change context on the evaluation of natural landscape", Landscape and Urban Planning, Vol. 43, No. 1-3, pp. 14 - 21. ISSN 0169-2046.

[38] Welch, B. L. (1947) "The generalization of "Student's" problem when several different population variances are involved", Biometrika, Vol. 34, No. 1-2, pp. 28 - 35. ISSN 1464-3510. 